\title{
VILLALPANDO’s SACRED ARCHITECTURE IN THE LIGHT OF ISAAC NEWTON’S COMMENTARY
}

\section{Tessa Morrison}

Abstract. The second volume of Ezechielem Explanationes by Juan Battista Villalpando, published in 1604, contains a re-creation of the Temple of Solomon illustrated by a portfolio of exceptionally detailed architectural drawings. His designs were built on the principles of Platonic musical harmonies and his interpretation of ancient measurements. Villalpando envisaged the temple as a building encapsulating the entire formal grammar of classical architecture. Villalpando's architecture, harmonic proportions and measurements appear to be a flawless system and his design exerted an extraordinary influence on the architects and historians of architecture in Europe for at least the next two centuries. His reconstruction inspired not only other commentaries and other reconstructions of Solomon's Temple, but it also stimulated discussion on the very origins of architecture. However, his reconstruction was not without its critics. In the seventeenth and eighteen centuries critics included Louis Cappel, Samuel Lee, Louis Compiègne de Veil, Nicolaus Goldmann and others who produced alternative reconstructions of Solomon's Temple. In the twentieth century criticism from what appears to be an unusual source was uncovered. In Sir Isaac Newton's unpublished manuscripts he claimed that although Villalpando had created the best of the reconstructions of the Temple of Solomon, the reconstruction had many problems. This paper examines Villalpando's reconstruction of the Temple in the light of Newton's unpublished commentary.

\section{Introduction}

The three-volume commentary on the Book of Ezekiel was to be a collaborative project by two Spanish Jesuits priests, Hieronymus Prado and Juan Bautisa Villalpando. Originally the project was led by Prado, and although it was to be collaboration, Villalpando's main contribution was to have been on chapters 40-42, which consist of Ezekiel's vision of the Temple of Jerusalem. The first of the three volumes was published in 1596 as Ezechielem Explanationes et Apparatus Vrbis Templi Hierosolymitani,2 and deals with the first twenty-six chapters of Ezekiel and was mainly written by Prado. However, Prado died before the publication of this volume and Villalpando was left to complete the project alone. Volumes Two and Three were subsequently published in 1604. Volume Two, De Postrema Ezechielis Prophetae Visione, contains Villalpando's famous reconstruction of the Temple along with his justification for it. Volume Three, Apparatus Vrbis ac Templi Hiersolymitani, consists of explanatory notes for the first two volumes. The overall project is a massive body of extraordinary and detailed scholarship. Villalpando was a highly skilled architect and draftsman and his reconstruction of the Temple is illustrated by a portfolio of exceptionally detailed architectural drawings. The project was an expressive one and it was only made possible through the financial support of Philip II of Spain.

Villalpando studied mathematics under the royal architect, Juan de Herrera, who at that time was involved with the construction of the Escorial. Herrera had an extensive library of books on the occult; these books indicated a strong interest in Hermetism, which is also supported by Herrera's treatise Sobre la figura cúbica [1935] on the Hermetic philosopher Ramón Lull. Fundamentally, Renaissance Hermetism promulgated a belief in an astrologically ordered cosmology where a geocentric universe was divided into three worlds: the world of man; the celestial world of the planets and the fixed stars, and the super-celestial world of God [Taylor 1972: 63-64]. The Christian Hermetism that was practiced in the Renaissance was a combination of Christianity and prisca theologia (ancient Knowledge). Ancient mystical mathematics of music, geometry and arithmetic became prominent in 
Renaissance Hermetism. This atmosphere of Hermetic learning pervaded the Spanish Court, affecting even Philip II himself, and Villalpando's In Ezechielem Explanationes was a product of this atmosphere.

\section{Villalpando's "flawless system"}

In Volume Two, Villalpando laid out a reconstruction of Solomon's Temple based on the vision of Ezekiel. Rudolf Wittkower described the rationale used in Villalpando's reconstruction as an "absolutely flawless system" [Wittkower 1988: 122]. This flawless system is a combination of: the three hermitic worlds of microcosm-macrocosm; the Pythagorean-Platonic musical harmonies; a cosmicastrologic plan which determined the plan of the temple precinct; Vitruvian anthropomorphism; and the module that governs the buildings. All of this was supported and justified by a deep knowledge of both Christian and Hebrew Sacred Scripture.

Villalpando clearly distinguished sacred architecture from the profane architecture of Vitruvius. He claimed that "Sacred architecture constitutes the origin of architecture, and the profane one is like a copy, or better still, like a shadow of sacred architecture" [Villalpando and Prado 1604: 414]. The purpose of Vitruvius, who Villalpando described as "the pioneer of our architects," was to equip the architect with the norms of architecture.

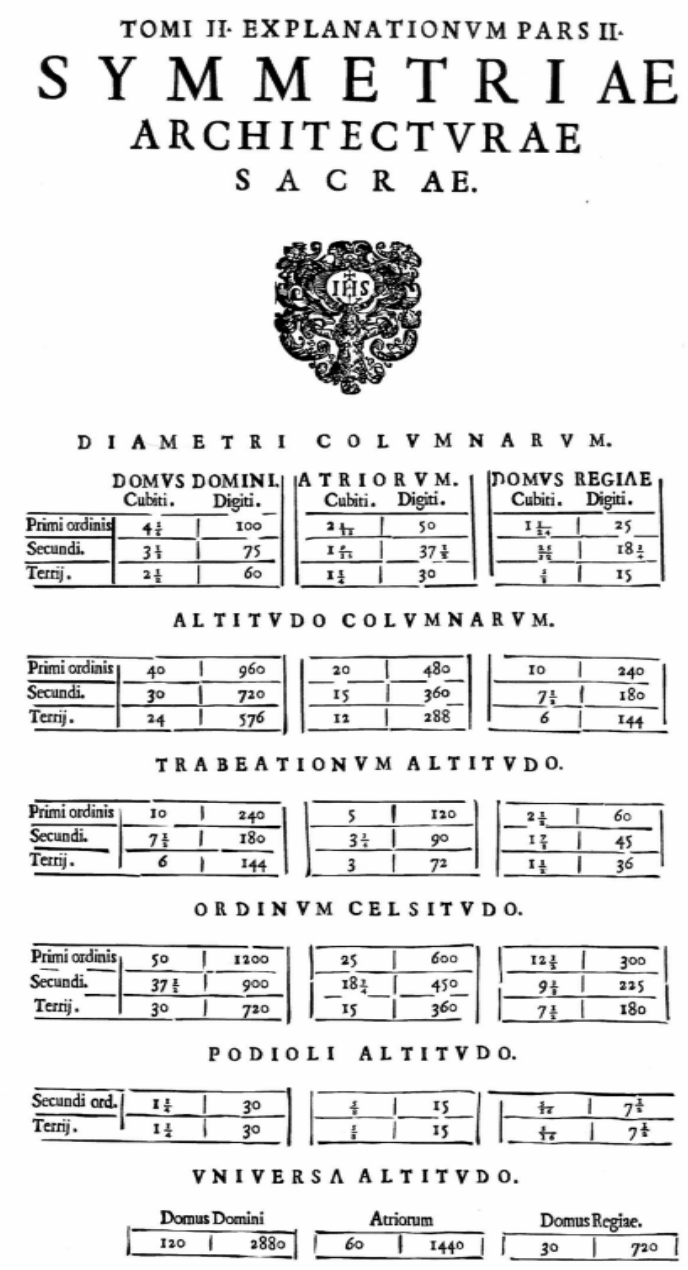

Fig. 1. Symmetry of Sacred Architecture. From Villalpando and Prado, Ezechielem Explanationes 
But Villalpando's purpose was to examine the origins of architecture and to extract the norms that were derived from God's plan and promulgated by the sacred scriptures; this natural order was followed by Vitruvius in his Ten Books on Architecture. Villalpando's reconstruction envisaged the Temple to be a building that encapsulated the entire formal grammar of classical architecture, which begins with the harmonic ratios.

Villalpando carefully defined all the measurements of the Temple as being derived from the sacred texts. He provides all the measurements of the three main floors of the buildings of Solomon; the measurements in column one are for the house of the Lord, in column two for the atrium, and in column three for the house of the king (fig. 1). These are grouped under the headings: the diameter of the columns; the height of the columns; the height of the entablature; the height of the floors; the height of the balcony and the overall height of the buildings. All of the measurements of the atrium are double that of the house of the King, and the measurements of the house of the Lord are double that of the atrium. In all of the columns the numbers reveal that the second floor is a quarter part smaller than the first floor, or a third part of its own measure smaller that the first floor; the third floor is a fifth part less than the second floor, or the fourth part of its own measure smaller than the second floor; proceeding in the same way it is possible to find out the other measurements of the other floors, i.e., the fourth floor will be a fifth part smaller than the third, or a sixth part of its own measure smaller than the third, and so on.

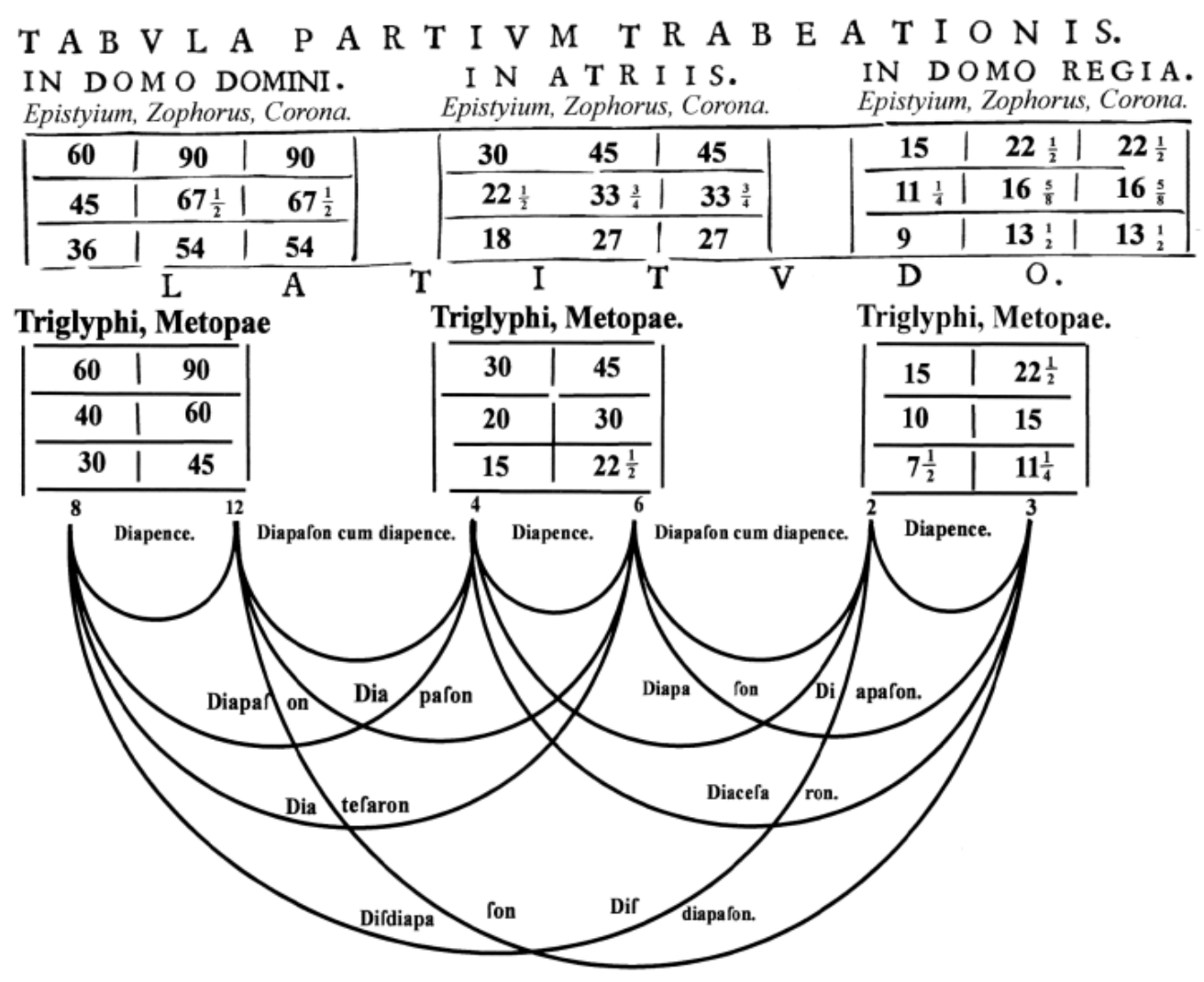

Fig. 2. Table of the Parts of the Entablature. From Villalpando and Prado, Ezechielem Explanationes

Villalpando also examined the heights of the columns and the entablatures (fig. 1). Considering the columns of the atrium, the overall height of the atrium is sixty cubits: the 
height of the first floor columns is twenty cubits, a third of the overall height, the height of the second floor columns is fifteen cubits, a quarter of the overall height and the height of the third floor columns is twelve cubits, a fifth of the overall height. Thus the above ratios are reflected in the height of the columns in relation to the overall height. The height of the entablature of the first floor is $1 / 12$ of the overall height; for the second floor it is $1 / 16$ the height and for the third floor, 1/20 of the overall height. The ratio between the first and the second floor is 4:3 and between the second and the third is 5:4 [Villalpando and Prado 1604: 441-443].

To deduce the heights of the entablature's elements, divide the height of the entablature by eight; two parts will be the height of the architraves and three parts each for the heights of the frieze and crown. The width of the triglyph and the metopes, are calculated from the distance between the centres of the columns. In the first floor the height of the architrave was equal to the width of the triglyph, and that of the metopes equal to the frieze (fig. 2). The width of the triglyph of the second floor to that of the first is in the ratio 3:2, and the third to the second 4:3 [Villalpando and Prado 1604: 449]. For Villalpando the proportions of the columns are the foundation of all other measurements and proportions of the entire temple [Villalpando and Prado 1604: 423].

Villalpando used the monochord to demonstrate the relationships between the widths of the triglyph and the metopes which resulted in intervals of the Pythagorean musical scale. Fig. 2 shows the inter-relationships between the three buildings of Solomon. Although Vitruvius outlined six harmonic ratios - the quarter (diatessaron), the fifth one (diapente), the eighth (diapason), the quarter of the eighth (diapason with diatessaron), the fifth of the eighth (diapason with diapente) and the double of the eighth one (disdiapason) [Vitruvius 1960: Bk. 5, ch. 4] - Villalpando rejected the quarter of the eighth. Throughout his commentary Villalpando followed Daniel Barbaro's commentary on Vitruvius's De Architectura; Barbaro opposed the musical theory of Vitruvius. For Villalpando "the quarter of the eighth, called 'superpatiens', is truly a dissonant chord, and consequently, the chords are simply five: three simple and two composed" [Villalpando and Prado 1604: 458].

Villalpando claimed that these harmonic proportions are most apt for a building of divine origins and he implied the existence of a link between the harmonic proportions and the celestial bodies. For Villalpando the Temple reflected the creation of God and thus had to incorporate itself into the universal harmony according to the movements of the planets and the fixed stars. To this end he examined the Tabernacle of Moses, since it prefigured the plan of the Temple. The camp of the tribes of Israel that surrounded the Tabernacle is a primitive plan of the Temple precinct [Villalpando and Prado 1604: 466]. Villalpando first established that the proportion of the atrium that surrounds the immediate temple and the altar is a double square; he then considered the configuration of the camp of the tribes of Israel. The configuration of the camp was highly structured, with the Tabernacle placed in the centre, fortified by the four camps of the Levites (Moses and Aaron; Caathi, Gerson and Merari). Surrounding them were the twelve tribes of Israel, each tribe camped under its banner that declared its ancient lineage. 


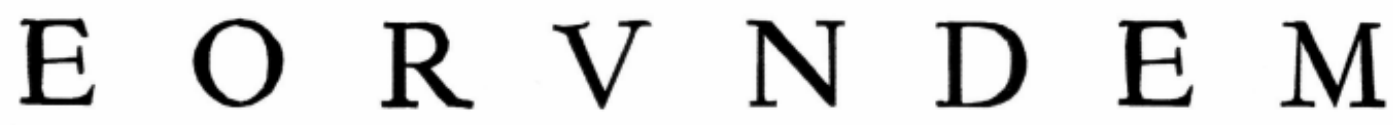 C A $S$ T R O R V M DISPOSITIO, MVNDVM referens, \& Templum.}

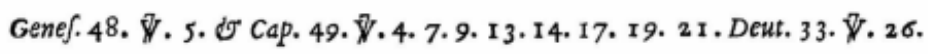

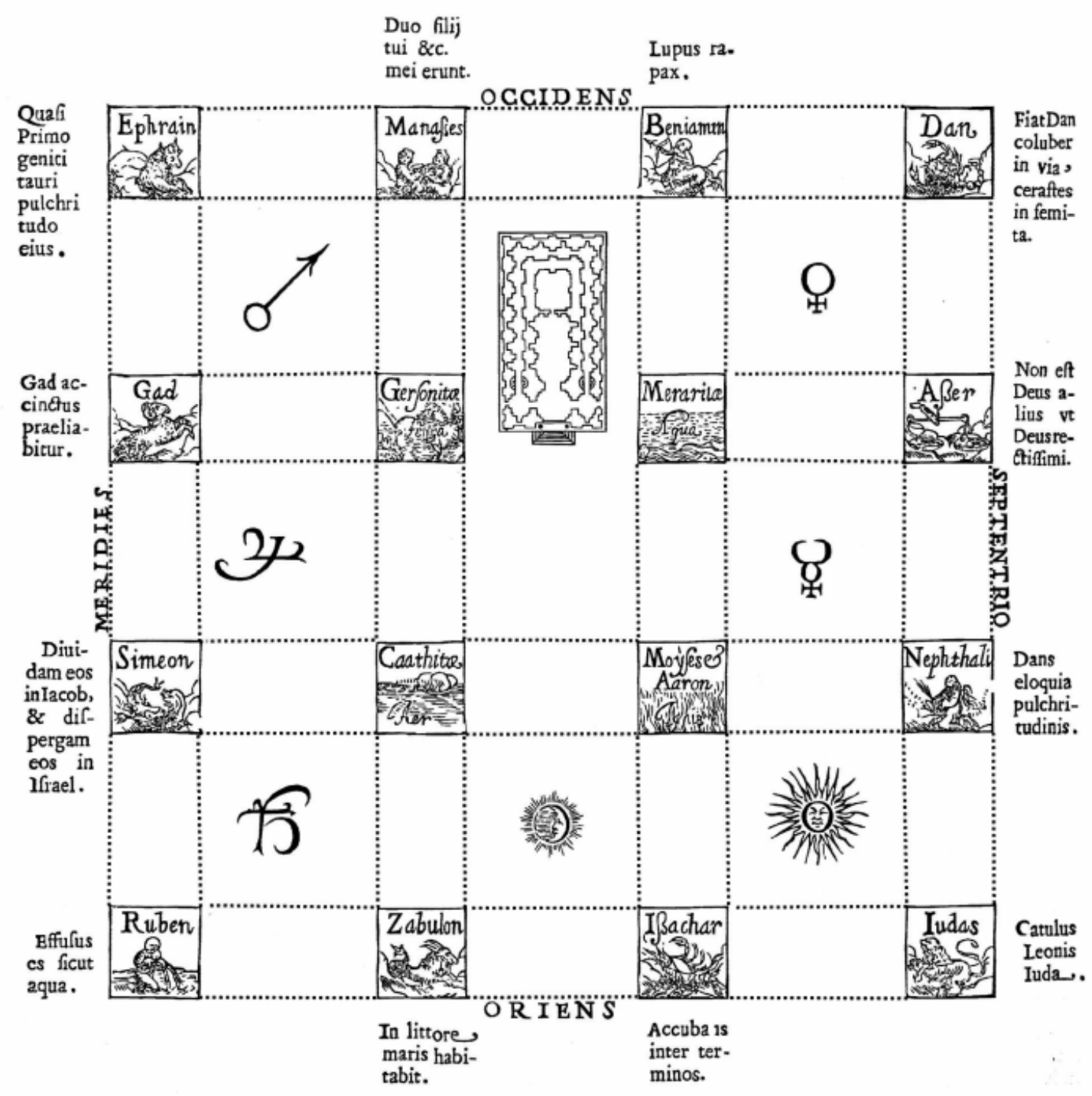

Fig. 3. The Arrangement of Heavenly Fortress. From Villalpando and Prado,Ezechielem Explanationes

The distribution and placement of the tribes in the camp was determined by a perfect plan with nothing left to chance, since it reproduced the plan of the Temple and thus was the microcosm of the universe (fig. 3). The four tents of the Levites in the center that fortified the 
Tabernacle corresponded to the four simple elements of the sub-lunar world, and represented the world of man. These were encircled by the celestial orbits made up of the seven atriums. The orbits are positioned on the plan as Ptolemy assigned them in Almagest: "Thus Saturn is situated between Capricorn and Aquarius; Jupiter in Pisces; Mars in Aries; Venus in Libra; Mercury in Virgo; the Sun in Leo and the Moon in Cancer” [Villalpando and Prado 1604: 469]. Surrounding the seven courts or celestial orbits were the twelve fortifications or bastions of the Temple precinct perimeter, which corresponded to the twelve tents of the tribes of Israel. Judah was represented by the lion, Ruben by the water-bearer, Ephraim by the bull, Dan by the Scorpion, and so on, so that the tribe's banners represented the signs of the zodiac. In the centre was the Temple, 'dedicated to the profit of man,' that represented the 'true Sun' of super-celestial world of the Church. This true Sun is Christ, the 'Sun of Justice' whose light is salvation. This light illuminates the seven planets and the twelve constellations, and the centralized Earth is illuminated by the Planet Sun that is located in Leo. This perfect plan represented the three worlds of the microcosm and macrocosm: in the centre was the super-celestial world of God; this is surrounded by the world of man; and this in turn is surrounded by the celestial world of the seven planets and the fixed stars encircling the Earth - a perfect hermetic vision of a geo-concentric universe.

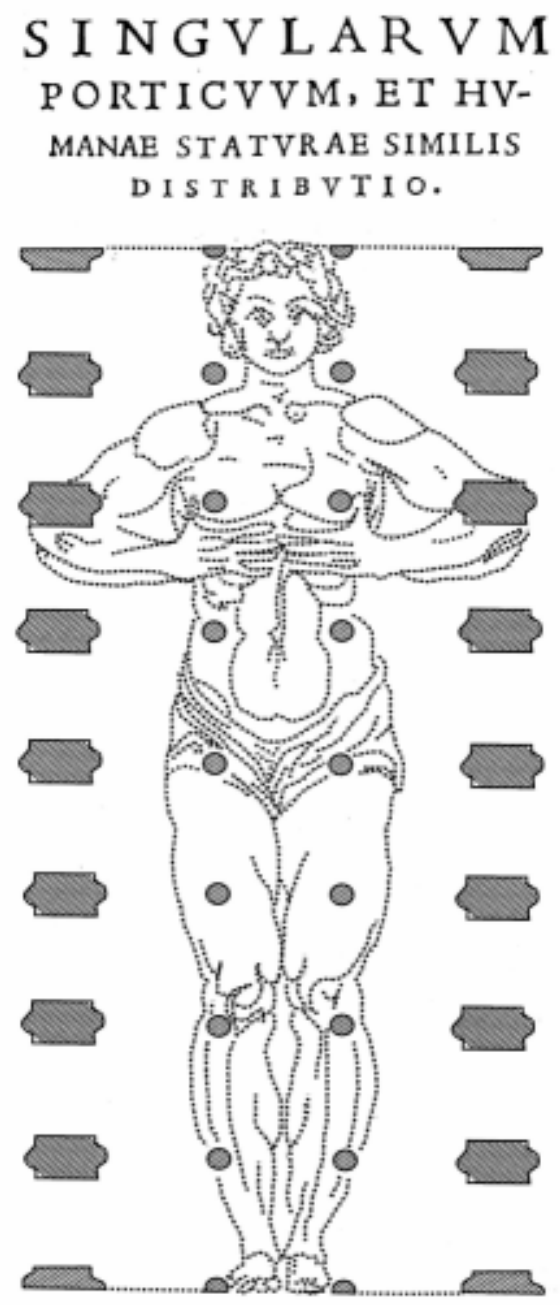

Fig. 4. A Single Colonnade and the Resemblances to the division of the Human Stature. From Villalpando and Prado, Ezechielem Explanationes 
Villalpando fully endorsed the anthropomorphic theories of Vitruvius. He perceived that the humanity assumed by God is reflected in the measurements and geometry of the Temple, which prefigured the perfection of the mystical body of the Church. Man has a height of six feet, and this measurement agrees with that of his arms extended; but if the arms are doubled in front of the chest, so that the end of the longest finger of the right hand touches the end of the middle finger of the left hand, then the width of man will be one and a half cubits, or three feet. The colonnades of the Temple have eight intercolumniations and are divided into three promenades or galleries that correspond to the barrel of the chest and with the arms (fig. 4). These colonnades correspond to the proportion of 1:2, not only a double square but also the harmonic ratio of an eighth, an octave. Here Villalpando portrayed Christ taking the appearance of man as the cosmological man, which emphasizes the microcosm macrocosm analogy.

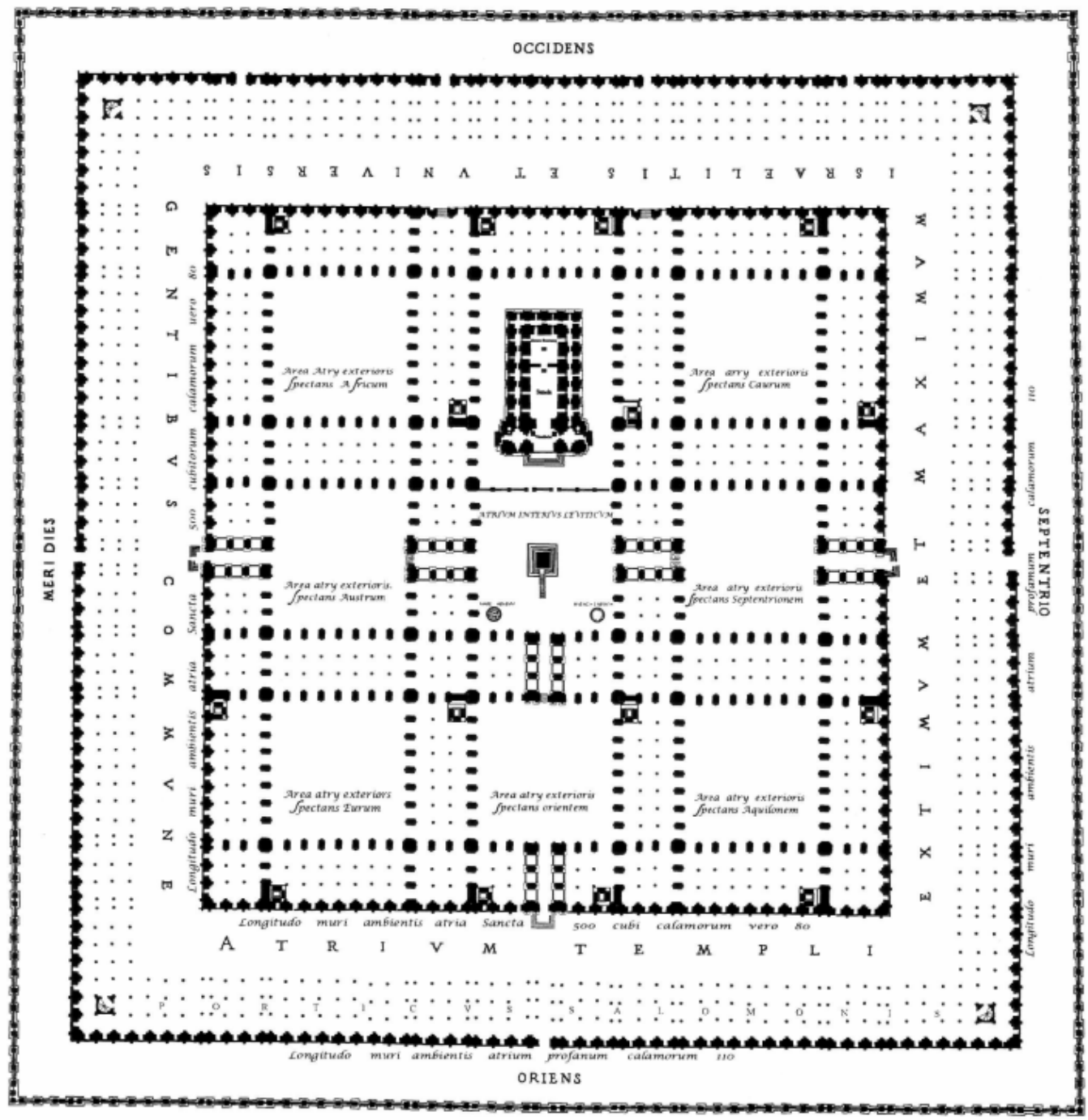

Fig. 5. Villalpando's Floor Plan of Solomon's Temple. From Villalpando and Prado, Ezechielem Explanationes

The gridded floor plan of Villalpando's reconstruction (fig. 5), corresponding to the plan that represented the three worlds of the microcosm and macrocosm, was crowded with colonnades and incorporated 1500 columns. The Temple precinct was 500 x 500 cubits and the exterior boundary $800 \times 800$ cubits. Its height including the foundation, was a massive 
420 cubits. Every part or element was in a harmonious ratio to the entire building. For Villalpando this was the greatest building ever built and no building could ever surpass it. His was the first full-scale reconstruction of the divine archetype and this reconstruction inspired not only other commentaries and other reconstructions of Solomon's Temple but it also stimulated discussion on the very nature of the origins of architecture.

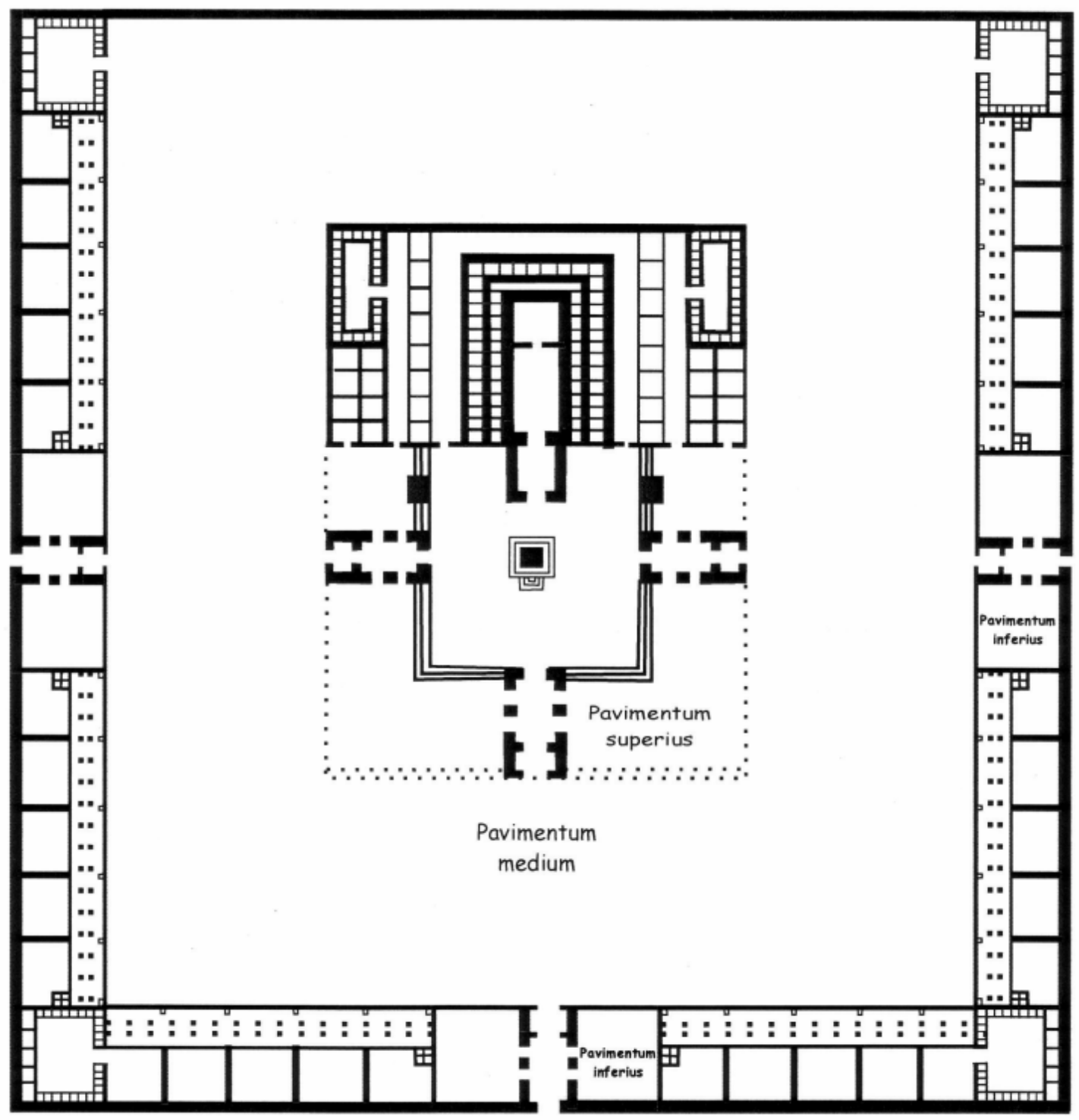

Fig. 6. Newton's Floor Plan of Solomon's Temple, copied by author from Babson MS 0434

However, his reconstruction was not without its critics. In the seventeenth and eighteen centuries, critics included Louis Cappel, Samuel Lee, Louis Compiègne de Veil, Nicolaus Goldmann and others who produced alternative reconstructions. 3 There were many points of disagreement between the critics, including whether Ezekiel's vision was the same as the Temple of Solomon, whether the architecture of the Temple could ever be surpassed, whether the Temple set the norms of architecture and thus was the origins of architecture. There was also a vast array of different interpretations of the sacred text, which resulting in many different reconstructions. Cappel wrote a commentary on Villalpando's reconstruction in Brain Walton's Biblia Sacra Polgotta [Cappel 1657], and a revision of this is in Critici Sacri [Cappel 1660]. Both contain large paraphrased sections of Villalpando's work, which 
continued to stimulate interest in Villalpando's work and Solomon's Temple; many of the later critics often quoted from the paraphrased version rather than from the original.

\section{Newton's commentary}

In the twentieth century, criticism from what appears to be an unusual source was uncovered. In Isaac Newton's unpublished manuscripts he claimed that "Villalpando, although the best [and] the most eminent commentator on Ezekiel's Temple: yet [he is] out in many things" [Newton, Yahuda: 32r]. Newton's unpublished manuscripts reveal that he had a long running interest in Solomon's Temple, yet the only published work of his on it was a very brief summary of the floor plan in The Chronology of Ancient Kingdoms Amended, which was printed posthumously in 1728 [Newton 1988]. Two of the Newton's manuscripts that contain a commentary on Villalpando are Prolegomena ad Lexici Propretici partem Secundam: De Forma Sanctuary Judaici) known under its call number Babson MS 0434 [Newton, Babson] and Miscellaneous Notes and Extracts on the Temple, the Fathers, Prophecy, Church History, Doctrinal Issues known as Yahuda MS 14 [Newton, Yahuda].

Newton's comments are a mixture of both support and criticism. Like Villalpando, Newton strongly believed that Ezekiel's vision of the Temple was the plan of Solomon's temple. In Babson MS 0434 he studied Ezekiel's vision of the Temple and confirmed this vision with readings of the ancient Hebrew and Greek texts. From this study he reconstructed the structure of the temple, revealing it to be mathematically perfect. However, his floor plan and description of the Temple are remarkably different from Villalpando's (compare figs. 5 and 6). He believed that Villalpando's errors in his design were primarily derived from his failure to take advantage of Jewish sources and his misinterpretation of the Latin texts [Newton, Yahuda: 32r]. Newton pointed to the Latin text that Villalpando used sometimes differed in its translation to the Hebrew texts, for instance in the Latin version in Ezekiel 42:3 Villalpando translated 'colonnades united' to be a triple colonnade but in the Hebrew text it translated to 'colonnade against colonnade three times' indicating three storeys [Newton, Babson: 12].

According to Newton, Villalpando created his grid plan of the Temple precinct from an “incorrect translation' and his plan "has no support and is lacking in reason" [Newton, Babson: 46]. Villalpando interpreted Ezekiel 40:19-20 as meaning that the length of the atrium from the south to the north is the distance between the gates, a hundred cubits, and this divided the area of the precinct into nine small atriums or anterooms, two of which formed the temple atrium and seven exterior to it (see fig. 5).These anterooms are divided from each other by triple colonnades fifty cubits wide. Newton pointed out that these anterooms not mentioned in Ezekiel. Regarding the thirty chambers that flank the sides of the gate, which are expressly mentioned by Ezekiel, it is impossible to arrive at the number 30 for these chambers if the spaces of the gates are not counted. However, this goes against the text of Ezekiel. In addition, Newton also claimed that Villalpando's grid plan cannot be accepted "unless we want to move away from the proportion of Moses' atrium that surrounds the immediate temple and the altar, which was established by Villalpando himself as being a length over double its width” [Newton, Babson: 46].

These criticisms based on Villalpando's interpretation of the Biblical texts challenge the basis of his reconstruction. The triple colonnades that Newton claimed was a mistranslation were important to Villalpando's plan. First, they portrayed man/Christ as the cosmological man, emphasizing the microcosm-macrocosm analogy. Second, they divided the gridded plan into the seven small ante rooms and the temple atrium, which Newton considers to be 'lacking in reason' and their creation goes against the proportions of the Temple atrium that Villalpando had himself established. These triple-colonnaded atriums not 
only formed a considerable part of Villalpando's reconstruction they are also significant for the plan of the three worlds of microcosm-macrocosm (fig. 3). Their removal from his plan changes his reconstruction so that it becomes unrecognizable. Furthermore, Newton referred to Villalpando's reconstruction as a 'fantasy' [Newton, Babson: 56]. All of these criticisms beg the question of why Newton considered him "the best (and) the most eminent commentator on Ezekiel's Temple?” In Yahuda MS 14 [32r-33v] Newton agreed with Villalpando's symmetrical layout of the camp around the Tabernacle and with the heraldry of the tribe's standards. He accepted that this plan prefigures the plan and the proportions of the temple, which were double that of the Tabernacle as proven in detail by Villalpando. In addition, Newton is in agreement that the prefect architectural harmony of the Temple represents a microcosm of the prefect harmony of the macrocosm. However, Newton misread Villalpando's geo-centric plan of the microcosm-macrocosm and considered it to be a heliocentric system. ${ }^{\mathrm{i}}$ Newton claimed that "Temples were anciently contrived to represent the frame of the Universe as the true Temple of the great God" (quoted in [Castillejo 1981: 33]). Newton established that Solomon's Temple was the model of all temples [Newton, Yahuda: $1 \mathrm{r}, 6 r]$. Thus this was the model microcosm of the universe and revealed the mind of the Supreme Architect, that is, the mind of God. This precise concentric model of the heliocentric universe is particularly strange given that Newton established the orbital paths of the planet to be elliptical before his making his comments on the Temple as the model microcosm of the universe.

A final point of agreement is that the Temple of Solomon was a masterpiece of architecture and was not only the model for all future temples but also established the norms of architecture as practiced by the later Greek and Roman architects and codified by Vitruvius [Newton, Yahuda: 32r]. In Newton's reconstruction the "capitals were carved in the Corinthian style of a beauty that was a miracle" [Newton, Babson: 15] and there were bronze Corinthian columns that were "covered with a great deal of silver and adorned with gold" [Newton, Babson: 19]. There were also massive Doric columns [Newton, Babson: 35, 38]; like Villalpando, Newton's reconstruction was the perfect classical building. In 1752, William Stukeley wrote his Memoirs of Sir Isaac Newton's Life. He recalled a conversation with Newton in 1725 on Solomon's Temple, where Newton claimed that the architecture of the temple was Doric and "the Greeks advanced it into Ionic and the Corinthian, as the Latins into Composite" [Stukeley 1936: 19]. But the architecture of Newton's reconstruction of 1680s is both Corinthian and Doric, and there is nothing in his papers to demonstrate this development, mentioned by Stukeley, of the architectural orders, or that he had ever changed his mind. Stukeley's reminiscences appear to support his own concept of architectural development rather that Newton's. For although Newton does not directly state that Solomon's temple was the pinnacle of architecture that could never be surpassed, he does point to proportions where "the columns will be less numerous than in the proportion of the eustyli of Vitruvius, and far more beautiful” [Newton, Babson: 37]. Architecture had not been improved by the Romans, but had in fact declined with the loss of a most beautiful proportion.

\section{Conclusion}

Newton's criticisms not only highlight fundamental errors in Villalpando reconstruction based on his interpretation of the scriptures but also point to inaccuracies in the rationale behind his "flawless" system. The anterooms and their divisions and the triple colonnades are features that are fundamental to both the Villalpando's architectural reconstruction and his concept of the microcosm/macrocosm. Although Newton concurred with the temple as the microcosm of the universe, he perceived this microcosm as a heliocentric system with the 
Temple as the hearth - the sun - of the universe, not the complex geo-centric universe of Villalpando. But despite In Ezechielem Explanationes being a book of the Renaissance and Newton's manuscripts being works of the Enlightenment, both Villalpando and Newton strongly believed in the medieval concept of the Divine Architect. In their architectural reconstructions they both attempted to find mathematical and geometrical formulations of divine truths. For Villalpando architects were the first Apostles, since they continued the work of the Divine Architect [Villalpando and Prado 1604: 464]. The image depicted by both is not far away from the thirteenth-century illustration of the Divine Architect wielding his compass in the Bodleian Bible Moralisé [Friedman 1974: pl. VII]. Yet their work remains exemplars of their respective periods, for the origins of architecture is to be found in the Temple of Solomon, which was the perfect model for all sacred architecture, and all profane architecture will ever be as a "shadow of sacred architecture."

\section{References}

CAPPEL, Louis. 1660. Excerpta Ex Villalpando Ad Ezechielem. In: Critici Sacri, John Pearson, ed. London.

- 1657. Trisagion Sive Templi Hierosolymitani Triplex Delineatio. In: Biblia Sacra Polgotta, Brian Walton, ed. London.

CASTILLEJO, David. 1981. The Expanding Force in Newton's Cosmos. Madrid: Ediciones De

Arte Y Bibliofilia.

FRIEDMAN, John Block. 1974. The Architect's Compass in Creation Miniatures of the Later Middle Ages. Traditio XXX: 419-429.

HARRISON, John R. 1978. The Library of Isaac Newton. New York: Cambridge University Press.

HERRERA, Juan de. 1935. Sobre la Figura Cúbica. Santander: Universidad de Cantabria. NEWTON, Isaac. Undated. Miscellaneous Notes and Extracts on the Temple, the Fathers, Prophecy, Church History, Doctrinal Issues, ets (Yahuda Ms 14). Unpublished manuscript, Jewish National and University Library.

- ca.1680. Prolegomena ad Lexici Prophtici partem secundam in quibus agitur De forma Sanctuarii Judaici (Babson MS 0434). Unpublished manuscript, Babson College, Massachusetts.

1988. The Chronology of Ancient Kingdoms Amended. London: Histories and

Mysteries of Man.

STUKELEY, William. 1936. Memoirs of Sir Isaac Newton. London: Taylor and Francis.

TAYLOR, Rene. 1972. Hermetism and Mystical Architecture in the Society of Jesus. Pp. 6397

in Rudolf Wittkower and Irma B Jaffe eds., Baroque Art: The Jesuit Contribution. New York: Fordham University Press, 1972.

VILLALPANDO, Juan Bautisa and Hieronymus PRADO. 1604. Ezechielem Explanationes Et

Apparatus Urbis Hierolymitani Commentariis Et Imaginibus Illustratus. Rome.

VITRUVIUS. 1960. The Ten Books on Architecture. Trans. Morris Hickey Morgan. New York:

Dover.

WITTKOWER, Rudolf. 1988. Architectural Principles in the Age of Humanism. London: Academy Editions. 


\footnotetext{
' In Chapter XXX of Ezechielem Explanationes Villalpando clearly describes and illustrates a geocentric system, where the Sun completes a circuit around the Earth every twenty-four hours. There is some ambiguity in the light of the centralised "Sun of Justice" Christ reflecting back to the Earth through the illumination of the planet Sun. However the planet Sun is circling the centralised earth. Villalpando clearly held a hermetic view of geo-centricism. Since he also lived and worked in Rome in the early seventeenth century, he would have been aware of, if he had not personally witnessed, the burning of Giordano Bruno in 1600 in Rome for promoting a heliocentric view of the universe. Furthermore, Ezechielem Explanationes was published in Rome and would have been censored if there had been any hint of the promotion of a heliocentric system. It is possible that Newton did not see the original volumes of Villalpando, and that his knowledge of Villalpando came from the paraphrased section of Cappel [1660], which is not as detailed as the original. It is known that Newton owned a copy of Cappel; see [Harrison 1978].
} 